To cite this Article: Mattila, A. and Mattila, M. (2016), "Discussing the Online Learning Premises," 2015 Fifth International Conference on e-Learning (econf), Manama, 2015, pp. 74-77.

DOI: 10.1109/ECONF.2015.20

URL: http://ieeexplore.ieee.org/document/7478215/ 


\title{
Discussing the online learning premises
}

\author{
Dr. Anssi Mattila \\ Education and Regional Development \\ Laurea UAS \\ Kerava, Finland \\ e-mail: anssi.m.mattila@laurea.fi \\ Dr. Minna Mattila \\ The Finnish Border Guard \\ Research and Information Services \\ Border and Coast Guard Academy \\ Imatra, Finland \\ e-mail: laalmatt@hotmail.com
}

\begin{abstract}
This paper takes a three dimensional approach - technological, human and practical - to highlight the elementary aspects of online learning premises. Today Learning Management Systems are complex applications, which offer faculty and learners many different tools to aid in implementation of an online learning experience. The students need to be empowered towards their own learning in a way that the educator appears as the facilitator of learning but won't directly teach the learners. The importance of communication dynamics grows even bigger in online learning because of the compilation of the independent nature of the learning environment and the directed nature of learning opportunities.1
\end{abstract}

Keywords-online education, eLearning technology, teaching, learning

\section{INTRODUCTION}

Technology creates and destroys jobs [1]. Nowadays, technology has changed the working habits as information technology has enabled virtual team work, remote work and distance learning, and part time jobs. Work tasks can be decentralised and completed regardless of the physical location or time of the day. [2]. This calls for flexibility from the workers - ability to cope with uncertainties and learn new things fast and constantly. [3]. Technology could also be perceived as an enabler; communication is possible even if the other person would be on the other side of the world. In the context of online learning, this means also stronger partners and new tools for the learner-educator interaction and relationship management. Communication is more real-time and frequent, and completing the learning activities becomes more efficient.

Studying online can enhance the necessary skill development enabling working in a technology enabled environment. Online learners are faced with the above described situations already while studying, and more likely to be more prepared to step into today's working life. Today, learners can utilise many different technologies to communicate with the educators, and communication does not have to be synchronous by nature. Educators and learners can attend courses when and where it best suits their schedules. This has also been noticed by the private sector and companies willingly utilise the latest online education technology as they have been doing for many years [4][5].

Information technology could also change the distribution of services dramatically. Some technological developments might even affect services', education including, contribution to creating value or excellent service quality. This will affect the kind of service encounter that will be required to provide the service in the future. Information technology encourages less face-to-face contact between service providers and customers. The need for personal contact will remain - at least for some time - but can be accomplished via the phone, e-mail, voice mail, or internet. The contact itself could get, however, even more personalised via IT [6].

1 This paper is based on the following previously published work: Mattila, A."The critical components of an online course syllabus" HASSACC2014, Mattila, A. \& Mattila, M."Building and maintaining an effective online learning community" SCIECONF2014, Mattila, M."Insights into the vocational education" EIIC2013, Mattila, A. "Society, working life and education - some core concepts"EIIC2013, Mattila, A. "' Online educators' Web 2.0 toolbox in LBD pedagogical model" ElIC2014, Mattila, A."Interactive services technology" GV CONF2014. 
A course is considered to be an online course if at least 80 per cent of the course content is delivered online while face-to-face instruction includes courses in which less than 29 per cent of the content is delivered online [7]. The latter mentioned one covers both the traditional seated classes as well as partially web facilitated courses. Online education can be offered in various ways, also in a blended, or sometimes referred to as a hybrid, form meaning that the number of face-to-face meetings has been reduced and 30- 79 per cent of the content is delivered online. [7].

\section{TECHNOLOGY ASPECTS}

Today Learning Management Systems are complex applications, which offer faculty and learners many different tools to aid in implementation of an online learning experience. Some of the features LMS might have include e.g. personalised catalogue, monitoring progress, web course design, collaboration tools, and course management tools [8][9]. To get a perfect picture of all the features, it might be sensible to search the Internet. An LMS has to provide all the means to implement an online course.

Using new online tools gives learners more realistic idea of what today's working life is like as well as what are the used online tools available there. For example, RSS feature enables the experience of inquiry acting when collecting research data for learning purposes. Obviously RSS will never replace the traditional ways of collecting research data, and it should not, but it is a great asset for learners for their learning purposes in projects. Furthermore, learners may acquire information for example of different sources of information and latest developments in research by observing the ongoing discussions in expert blogs.

Interactive learning environments challenge learners by offering new opportunities and new tools for learning. They also assist the learner to develop his/her critical thinking skills and encourage learners to use their full potential. Web 2.0 enables more efficient and real-time use of resources (educators, learners, practitioners and working life mentors, information and knowledge). Some of the online educator's Web 2.9 tools could include for example:

- Blogs

- Wikis

- RSS and aggregators

- Online photo galleries

Thousands of online learners and educators have taken blogs in use, which are easy to create and update. Wikis can be co-created and revised by anyone online but also protected by passwords, if needed to ensure the correctness of the learning objectives. RSS allows subscribing feeds from content published online while aggregators collect and compile syndicated content using RSS feeds. A participation in a photo gallery could prove to be an asset for an online educator as sometimes "picture tells more than thousand words".

Podcasts can also be used for learning purposes online and the students themselves can self-produce digital content.

\section{HUMAN ASPECTS}

Traditionally, the use of technology in higher education has enabled communication and collaboration. Today, it transcends the physical distance, offers a faster transfer of knowledge and quicker feedback. [10]. The collaborative nature of Web 2.0 tools has enabled efficient peer learning also in an online community. An electronic online learning platforms (e.g. Blackboard, Moodle, Izio, Jenzabar, eCollege, WebCT) have been used to facilitate online learning but the inclusion of collaboration tools (e.g. Skype, Twitter, Flickr, Google Docs, Facebook, Google Earth) enhancing online learning is likely to promote entirely new ways of interaction:

o Multiple collaborators can contribute to effective interaction

o Collaboration is more synchronous and can be saved for an asynchronous viewing

o Role-based sharing is an option

o Collaborators become more discoverable (by location, by shared interests, or other)

o Collaborators can modify and thus contribute to the work of others

o Collaboration becomes more playful, social and thus engaging [10].

According to the theory of Social Learning people learn by observing each other [11]. One could imagine that this sort of learning is also very common within the online learning communities. Adults are known to observe and learn from each other's behaviour, for example at a dinner table where it is hard to remember which fork to choose first... Even such ordinary events and observations may lead to learning and next time, the observer remembers and knows how to apply the information he or she gained by means of observing. 
Learning based on observations is not fully risk free, though. What if the "educator" being observed does not know how to behave or do things him/herself. This might lead to a false learning.

According to the Social Learning school of thought human behaviour is learnt in a pleasant environment and in interaction with other people [11]. I would say that social learning can offer opportunities for adult learner groups in particular where the learning partially comprises of sharing (working life) experiences. In order to enable social learning in a student group, the spirit must be supportive and encouraging enough to have the students in the group to share their knowledge and prior experiences with each other and thus enable learning from each other as well. An educator can act as a moderator or a facilitator structuring the discussion. This is relatively easy to accomplish in an online environment.

When creating an effective learning environment, also online, inspiring students to learn with the joy of learning is essential. Clear objectives can help the learner feel more secure together with formative and summative assessment. The students need to be empowered towards their own learning in a way that the educator appears as the facilitator of learning but won't directly teach the learners. [12]. Effective learning environment also includes strategies that educators use to create a positive, productive classroom experience. Effectiveness can consist of for example preventing interruptions, handling routine procedures yet using engaged time effectively, and maintaining momentum, smoothness of instruction, and group focus during lessons. [13]

Learning experience is all about the communication dynamics within the learning environment which are the critical success factor in the learning experience. The importance of communication dynamics grows even bigger in online learning because of the compilation of the independent nature of the learning environment and the directed nature of learning opportunities. Baker et al. (2005) believe that "online learning puts an added responsibility on the instructor to foster a communication-rich learning community". It goes without saying that a better comprehension of social dynamics assists online instructors to support an effective (online) learning community [14].

The online community offers a natural community for peer learning. It is expected to energise the students as they are able to help each other to learn [15]. Some of the methods to get started with communal scaffolding in online learning include getting started with the online interaction and facilitating dialogue and online participation. Instructor responsibilities comprise of what could be called as administrative duties and teaching and even coaching tasks. The instructor must be prepared to have the necessary hardware and software in use together with required textbooks and other teaching materials but perhaps even more importantly, setting the tone at the start of the online course is perhaps the most important factors of an effective online learning environment.

As in seated-classes, students learn from the instructor's behaviour online. The instructor needs to be sure to use netiquette in his/her online class and to demonstrate respect towards the students and diversity. The set tone will follow for all times throughout the online course [16]. Setting up a proper tone of academic discussion makes students feel valued. Students will appreciate online instructors who are flexible, fair, and impartial when dealing with the students. At times, you may need to teach something to a student in a different manner than it was presented - being aware of the different learning styles of students - and this goes to varying your tone as well. West et al. (2004) have argued that "knowing the tone you want to set will allow you to shape the climate of your class for success" [16].

The main tool for giving lectures online is the threaded discussion. Active learning techniques which are aligned with the learning outcomes must be introduced to support the learning online. Meaningful discussions are the key to keeping up a dialogue online and facilitation frequent online participation [17], which on the other hand are variables of an effective online learning community. Timely online discussion participation, analytical and interpretative responses and scholarly dialogue contribute to a meaningful online discussion. The relevance of the postings and comments should be explained in sufficient detail. They can also be used to deepen the discussion or even give constructive feedback. The importance of active instructor participation online cannot be emphasised enough. An online instructor can for example use the threaded discussions as a place to expand upon the course material by providing expertise and experience. An online instructor never leaves his/her students alone online but instead, spurs student-to-student discussion by encouraging the students to post comments, thoughts, and questions to others' comments on the discussion board(s). 
When starting to teach a new course, which means starting to create a new online course syllabus, there's always a certain level of uncertainty in the air. The group dynamic is new and you as the instructor find yourself facing new challenges. When starting to draft a course syllabus for an online course, the mnemonic "T.R.E.E." is helpful: tone, rules, expectations, engagement. The way how well you will be able to establish these principles already at the syllabus writing stage will define the rest of your course.

$\square$ Tone - in an online learning environment, punctuality still matters. Your course syllabus must show to the students that you value readiness to learn. You can establish the principle of punctuality online by having everything ready to go on your course website from the first moment the students see it [18]. This means that the course syllabus must be finished well before the course starts!

$\square$ Rules - a trip around the syllabus with the students at the start of your course is crucial to make sure that you have stated its provisions for the record [18]. However, you need to collect feedback in how well (or not) the students actually have understood the course syllabus, too. You cannot start changing the course syllabus in the middle of the course but you can revise it by next time you teach the same course, and learn from your own mistakes in setting the rules before the course start. What's not in the course syllabus, doesn't exist...

$\square$ Expectations - the course syllabus sets up the student expectations of what they will learn on the course, how you will teach the course, what are the course requirements, and so forth. Besides creating student expectations, syllabus is the place to present yours! One of the expectations might be that the students familiarize themselves with the course syllabus... You could apply the Bloom's Taxonomy to develop expectations for the students [19]. The students who are deserving of an A would be capable of doing all of the below mentioned ones while a student doing $B$ work is able to product about 80 percent of the listed expectations, and so forth.

o Knowledge / Memorization: student recalls methods, procedures, abstractions, principles, theories, facts, conventions, definitions, jargon, classifications, criteria

o Comprehension / Understanding: student understands and grasp the meaning of knowledge and articulates connections between different items of knowledge o Application / Using: student uses abstract ideas in concrete situation o Analysis / Taking apart: student breaks down complex problems and solves each part using principles and theories common to his/her discipline o Synthesis / Putting together: student puts parts together to make a whole new entity of concepts

o Evaluation / Judging: student makes judgment about a solution, design, report, material by using internal and/or external criteria [partially adapted from 19]

Engagement - a good online course syllabus in engaging. You might want to build your first course activity so that the students have no need to rely on the course text [18] as some of them may not have access to it for the first course week or so. This is likely to increase the level of student engagement as the student won't be able deny themselves from the online participation due to the missing course text...

A good online course syllabus, sometimes also referred to as course outline, introduces at least the following topics in sufficient detail:

$\square$ Basic course information

$\checkmark$ Course materials

$\checkmark$ Course description

$\square$ Course goals

$\square$ Learning objectives

$\checkmark$ Additional information

$\checkmark$ Academic dishonesty

$\square$ Study methods

$\square$ Disability disclosure

$\square$ Assessment

$\checkmark$ Grading standards

$\square$ Course schedule 
Creating a good syllabus isn't just about describing the outcome but it's also about combining the course goals and learning objectives to the course activities. A solid course syllabus is especially essential tool in the online environment where students cannot meet with the instructor face-to-face. Both the students and the instructor can rely on a good and informative course syllabus for the whole duration of the course.

\section{CONCLUSIONS}

Regardless of the rapid technological development online learning and online learning environment include elements having longer lifespan than evolving technology. In an online learning environment it's easy to lose yourself in the jungle of developing technologies and online tools. Even though technology provides the means to communicate with the students and the ways to deliver your course, sometimes in online learning environment, less can be more too. When starting to craft your online course, the mnemonic T.R.E.E. is worth remembering - tone, rules, expectations and engagement.

\section{REFERENCES}

[1] R. Rinne and E. Salmi, Oppimisen uusi järjestys, Tampere: Vastapaino, 1998, pp. 72

[2] R. Rinne and E. Salmi, Oppimisen uusi järjestys, Tampere: Vastapaino, 1998, pp. 95-96

[3] R. Rinne and E. Salmi, Oppimisen uusi järjestys, Tampere: Vastapaino, 1998, pp. 99

[4] M. Regan, "Utilizing the Internet in education," College and University, American Association of Collegiate Registrars and Admissions Officers, vol. 76, issue 4, Washington, US, 2001.

[5] R. A. Ghani, "Exploring benefits of online education: [Computimes, 2* Edition]," New Straits Times, Ther New Straits Times Press (M) Berhad, Kuala Lumpur, Malaysia, 2001.

[6] H. Kasper, "Remote Service Delivery in Services Marketing at the Turn of the Millennium," in Services Marketing at the Turn of the Millenium: What Will Keep Senior Managers Awake at Night and What Should They Do About It! . Marketing Management, Autumn issue, 1997

[7] E. Allen, J. Seaman, Staying the Course. Babson Park: The Sloan Consortium, pp. 1, 2008.

[8] S. Hall \& B. Hall, " A guide to learning content management systems," Training, 41(11), pp. 33-37, 2004

[9] H. Hills, "Learning management systems: Why buy one?,"TrainingJournal, ProQuest Central, 2003.

[10] C. Lomas, M. Burke, C. Page, "Collaboration Tools", Educause Learning Initiative, No. 2, 2008, pp. 2-11.

[11] P. Ruohotie, Oppiminen ja ammatillinen kasvu. Porvoo: WSOY, 2002, pp. 115-118

[12] Cdtl 2008. http://www.cdtl.nus.edu.sg/link/jul2003/learn2.htm as available on 18 April 2008.

[13] Ablongman 2008. http://wps.ablongman.com/ab_slavin_edpsych_7/6/1666/416684.cw/index.html as available on 18 April 2008.

[14] J. Baker, R. Woods, "Social Dynamics of Online Learning: Pedagogical Imperatives and Practical Applications", 18th Annual Conference on Distance Teaching and Learning, 2005, pp. 1-5. Unpublished.

[15] R. Paloff, K. Pratt, The virtual student: A profile and guide to working with online learners. San Francisco: Jossey-Bass. 2003.

[16] R. West, L. Turner, Introducing communication theory: Analysis and application, 2nd ed. Boston: McGraw-Hill. 2004.

[17] R. Frazee, "Using Relevance to Facilitate Online Participation in a Hybrid Course", Educause Quarterly, No. 4, pp. 67-69, 2003.

[18] R. West and L. Turner, Introducing communication theory: Analysis and application, 2nd ed. Boston: McGraw-Hill. 2004.

[19] The Bloom's Taxonomy (2008). Presented in the online instructor orientation material by the University of the Incarnate Word Universe Online as an example of how Bloom's Taxonomy is used to develop expectations for students in an engineering program Available: http://www.che.wsu.edu/ millerrc/bloom.html 